Volume 13

Issue 2 Rethinking Genocide, Mass Atrocities,

and Political Violence in Africa: New Directions,

Article 19

New Inquiries, and Global Perspectives

\title{
6-2019
}

\section{Film Review: The Uncondemned}

Jessica M. Adach

Kingston University

Follow this and additional works at: https://digitalcommons.usf.edu/gsp

\section{Recommended Citation}

Adach, Jessica M. (2019) "Film Review: The Uncondemned," Genocide Studies and Prevention: An International Journal: Vol. 13: Iss. 2: 165-167.

DOI:

https://doi.org/10.5038/1911-9933.13.2.1636

Available at: https://digitalcommons.usf.edu/gsp/vol13/iss2/19

This Film Review is brought to you for free and open access by the Open Access Journals at Digital Commons @ University of South Florida. It has been accepted for inclusion in Genocide Studies and Prevention: An International Journal by an authorized editor of Digital Commons @ University of South Florida. For more information, please contact digitalcommons@usf.edu. 


\section{Film Review: The Uncondemned}

\section{Acknowledgements}

Footnote from page two of the review, in reference to the thousands of women and girls raped during the Rwandan Genocide. Binaifer Nowrojee. Shattered Lives: Sexual Violence during the Rwandan Genocide and its Aftermath. (New York: Human Rights Watch, 1996), 1. 
Film Review: The Uncondemned

Jessica M. Adach

Kingston University

London, England

The Uncondemned

Directors: Nick Louvel, Michele Mitchell

Netherlands, Congo, Rwanda, USA, 2015

Reviewed by Jessica M. Adach

Kingston University

The opening frame of the film, The Uncondemned, reveals a quotation from Ghengis Khan, perhaps the most notorious figure of rape and conquest in history: "The greatest pleasure in life is to vanquish your enemies... to see those dear to them bathed in tears... to clasp to your bosom their wives and daughters." The emphasis is placed on women and girls as both targets and objects of suffering. Indeed, as the film progresses we understand that women and girls were brutalized during the Rwandan genocide and forced to live with wounds that may never heal. In some cases, perpetrators refused to kill the women after their rape - regardless of how much they begged leaving them instead to "die of sadness."

The Uncondemned masterfully documents the case of Jean-Paul Akayesu, the mayor of a small Rwandan town and perpetrator of genocide, who stands trial in the International Criminal Tribunal for Rwanda, first international criminal tribunal since Nuremberg. He is also the first person to be charged with genocide, including the charge of rape.

Through the first five minutes of the film, documentary footage and photographs flash across the screen in a compelling narration of the chronology of the Rwandan genocide: the tension between Hutus and the Tutsis who had been favoured by colonizers, widespread propaganda promoting hate, the violent warning signs identified by United Nations peacekeeping forces led by Romeo Dallaire that were rejected and ignored by the international community, and the slaughter of one million people in one hundred days while the world watched. The genocide is also situated within the broader context of the geo-political landscape of 1994 which included the conflict in Bosnia that captured the attention of the West.

The filmmakers ease into present-day Rwanda, bridging the gap between past and present by showing current memorials for those that perished. Haunting, instrumental music fills the scene as the camera leads viewers into a church where 10,000 Rwandans were killed. This site continues to be their final resting place as skulls, clothing and personal effects such as eyeglasses remain untouched. Bullet holes pepper the roof casting light onto the remains. On a medical table in the sterile basement of the church lays a large crucifix with sharpened points. We learn about Mukandori Anonsiyata, aged 26, who was held hostage and raped for days, finally being murdered with such a stick as it was forced upwards through her body into her skull. They can't preserve the memory of each woman who was raped, comments a narrator who is likely the museum curator, as there are too many. Instead Mukandori Anonsiyata represents the suffering of all women who faced sexual violence during the genocide.

We are taken to Taba, the rural community where Akayesu served as mayor. The rolling hills set the scene of the genocide, the beauty of the landscape juxtaposed with the atrocities that took place there. It is in this town that the key players of this story come together.

Pierre Prosper, the young lawyer who took charge of the case, with a background of prosecuting gang violence in Los Angeles; Sara Darehshori, a lawyer and investigator sent to build the criminal prosecution; Binaifer Nowrojee, an activist and investigator for Human Rights Watch; Patricia Sellers, legal gender advisor based in The Hague; Rosette Morrison, investigator and support to witnesses; Thierry Crubellier, journalist; Lisa Pruitt, gender consultant; Godelieve Mukasarasi, genocide survivor and founder of a women's organization in Taba; and local women from Taba who lived through the genocide. 
Each of these individuals is interviewed and featured throughout the film, their retelling of events the integral source - alongside documentary footage - of the Akayesu case. Cameras focus on the interviewees, who are typically seated against a black backdrop, drawing attention singularly to their story as they recount their experiences to unseen filmmakers.

Through Nowrojee's work with Godelieve Mukasarasi, genocide survivor and founder of a local women's organization SEVOTA, the horrific accounts of rape that occurred in Taba come to light: women who had been held naked and captive for days, gang raped, genitalia mutilated and left on display. While these stories conjure graphic images, it is important to understand the extent to which women suffered, and build the case for why rape should be added to Akayesu's indictment.

These detailed accounts also serve to illustrate how militia used sexual violence within the Rwandan genocide more broadly. Rape, sexual slavery and mutilation were used as a tool to manipulate, torture and instill fear amongst girls and women, and to threaten and degrade the Tutsi ethnic group. The sexual violence that took place in Taba was also widespread across the country, with thousands of girls and women raped during the genocide. ${ }^{1}$

There were many layers of complexity lawyers faced when working on this case. Fifteen members of the legal team came from eleven different countries, speaking different languages bringing experiences from their own jurisdictions, leading to debates over protocols and practices that should be applied. While the prosecutors had a background in common law, the judges each served in civil law systems. Office supplies were at a minimum; Prosper shares a story of attending a meeting to determine how the team's final stack of paper should be most effectively used. A photograph of Darehshori sitting in an empty office at a desk void of any supplies confirms how few resources were available. These anecdotes are stark reminders of the context in which the legal team was working, an international effort in a country reeling from the aftereffects of genocide.

The legal team faced a critical challenge when a witness, Emanuel Rudasingwa, was gunned down together with his daughter and nine others. Rudasingwa was the husband of Godelieve Mukasarasi, the interlocutor who had assisted in gaining evidence from the women of Taba to build the case of rape against the defendant.

Perhaps the most complex issue in formulating the legal case involving rape as a crime of genocide was around the definition of genocide itself. While rape is listed as a possible criterion to define genocide, until this point it had not been included in an international criminal charge. Genocide involves the intent to destroy a group - national, ethnic, religious - in whole or in part. A Rwandan psychologist interviewed in the film describes that rape not only shatters the life of a woman or girl, but also devastates the wider community, having long-lasting familial, social and economic implications. Through explanations from experts, filmmakers ensure the issue of rape within the crime of genocide is presented clearly, illustrating the multifaceted challenges of the case.

Through a witness statement it becomes clear that there is a strong case for adding rape to Akayesu's indictment; he knew of and allowed the rape and violence perpetrated against girls and women on the compound where his mayoral office was located.

Documentary footage is once again introduced to complement the present retelling of the trial. The case comes to life as Judges Kama, Aspegren and Pillay, the young lawyers and the accused Akayesu appear on screen and details of the case are revealed. At certain points filmmakers use subtitles - both in French and English - displayed on screen against a black backdrop, emphasizing the impact of the words, drawing the focus to their meaning.

Sellers, the prosecution's gender advisor based in The Hague, recalled a powerful message the group of witnesses repeated to themselves before entering the courtroom to testify: they would speak their truth, say only what they saw, not heard, in order to obtain justice, not revenge. These women had travelled by plane from their rural villages, where many did not have access to running water, to raise their voices against the man responsible for the violence they had endured and witnessed. On September 2, 1998, as a result of their testimony, Akayesu was found guilty of crimes against humanity including rape, along with genocide and incitement to commit genocide.

${ }^{1}$ Binaifer Nowrojee, Shattered Lives: Sexual Violence during the Rwandan Genocide and its Aftermath (New York: Human Rights Watch, 1996), 1. 
In a powerful moment, the Rwandan women who had been interviewed during the film each identify themselves as they key witnesses that had been referred to using pseudonyms throughout the case.

By focusing on the case of Akayesu, initially thought of as a minor player when considering the key figures perpetrating the Rwandan genocide, the filmmakers reinforce that genocide and crimes against humanity can manifest even in a small community, perpetrated by a seemingly ordinary man, and that these transgressions must not be deemed any less significant. In some ways, the story of Akayesu and the women of Taba may make an even more impactful statement than the case of a well-known genocidaire. It declares to the world that when legal frameworks and are in place and operational, there is no place where perpetrators should face impunity, where justice cannot reach. The success of this case now serves as a model, a blueprint for how to navigate indictments of genocide and rape.

Just as the church memorial safeguards the memory of Mukandori Anonsiyata who represents the women of Rwanda who experienced sexual violence during the genocide, so too does the case of Akayesu represent the legal victory of genocide and rape convictions which have laid the foundation for international justice on these charges into the future.

As the credits begin to roll, a final scene shows three former interahamwe militia - now accused of thousands of rape cases in neighbouring Democratic Republic of the Congo - waiting to be interviewed by the filmmakers. When asked if they employed rape as a tactic of war, there was silence, each man looking at the other to reply. The film ends with their silence, a symbol that they are now powerless, their voices muted against the testimony of the women who sought justice.

The Uncondemned depicts the powerful journey towards the critical achievement of rape being recognized both in the history of international criminal tribunals in cases of crimes against humanity and genocide, and also for women and girls - and men and boys as well - who have suffered sexual violence at the hands of perpetrators during conflict. It is likely that this film will have lasting relevance and go on to educate students and practitioners on both the Rwandan genocide as a whole, and how rape can be confronted in convictions of genocide.

Title of the Film: The Uncondemned; Directors: Nick Louvel, Michele Mitchell; Producer: Michele Mitchell; Screenplay: Michele Mitchell; Music: Nicholas Britell; Cinematography Nick Louvel; Film Editor: Nick Louvel; Countries: Netherlands, Congo, Rwanda,USA; Languages: English, French, Kinyarwanda; Year of Release: 2015; Production Company: Film at Eleven. Duration: 81 minutes.

\section{Acknowledgments}

Footnote from page 166 of the review, in reference to the thousands of women and girls raped during the Rwandan Genocide. 